\title{
Ecological Hermeneutics and the Interpretation of Biblical Texts Yesterday, Today and Onwards: Critical Reflection and Assessment
}

\author{
Kivatsi J. Kavusa (University OF Pretoria)
}

\begin{abstract}
This article critically explores various approaches in which interpreters operate in recent attempts to apply ecological hermeneutics to biblical texts. It engages with the strengths and weaknesses of the works of the apologetic readers (reading of recovery), the Earth Bible Project (reading of resistance 1), the anti-ecological reading (reading of resistance 2), the revisionist readers (mostly the Exeter Project), the Eco-Feminists and the Eco-theological voices of African scholars. Finally, the article draws critical evaluation, assessment and acknowledgment of the need of complementary insights from different reading stances. Finally, the article argues that, for a fruitful ecological reading of the Bible, one must admit that biblical texts were formulated in a world that knew nothing about modern ecological problems. Thus, the aim of a fruitful reading should direct the reader towards the critical power and relevant stimulus of biblical texts for our questions. In whichever reading, the interpreter is invited not to mix in one mould the biblical statements and his/her current realities. This means that our realities should never dictate the direction of biblical interpretation, but both worlds should remain in a constantly enriching dialogue.
\end{abstract}

KEYWORDS: ecological hermeneutics, recovery reading, resistance reading, revisionist reading, eco-feminist reading, Earth Bible Project,

\section{A INTRODUCTION}

Lynn White's article, "The historical roots of our ecological crisis" placed the blame for the modern ecological crisis upon Western Christianity and its anthropocentric traditions. According to White $^{1}$, Christianity is the most anthropocentric religion the world has ever had as it establishes a dualism between humanity and nature, insisting that it is God's will that human beings exploit nature for their own ends.

\footnotetext{
* Submitted: 10/10/2018; peer-reviewed: 21/11/2018; accepted: 19/02/2019. Kivatsi Jonathan Kavusa, "Ecological Hermeneutics and the Interpretation of Biblical Texts Yesterday, Today and Onwards: Critical Reflection and Assessment," Old Testament Essays 32 no. 1 (2019): 229-255. DOI: https://doi.org/10.17159/2312-3621/2019/ v32n1a13.

1 Lynn White, “The Historical Roots of our Ecological Crisis," Science 155 (1967): 1205.
} 
Lynn White's article sparked heated debates among biblical scholars and theologians as to its claims that the rape of the earth had been authorised by the dominion mandate of Genesis 1:26-28 in which humans regard themselves as superior beings (imago dei) and the centre of the cosmos. According to White, "we shall continue to have a worsening ecologic crisis until we reject the Christian axiom that nature has no reason for existence save to serve man."2

Theologians and eco-theologians reacted to White's allegation by either demonstrating the eco-friendliness of biblical traditions or resisting these traditions This article critically investigates various hermeneutics in which interpreters have operated in recent attempts to apply ecological hermeneutics. It engages with the strengths and weaknesses of the works of the apologetic readers (reading of recovery), the Earth Bible Project (reading of resistance 1), the anti-ecological reading (reading of resistance 2), the revisionist readers (mostly the Exeter Project), the Eco-Feminists and the Eco-theological voices of African scholars.

The first part offers a brief overview of the definition of key terms. The second part is an exploration of prevailing ecological approaches in which scholars operate today. The final section focuses on the critical evaluation and suggestions.

\section{B DEFINITION OF THE KEY-TERMS}

\section{Hermeneutics}

The term hermeneutic derives from the Greek verb hermēneuō. The verb alludes to the act of imitating the mythological god Hermes whose task consisted of "transmuting what is beyond human understanding into a form that human intelligence can grasp"3. This means that the word hermeneutic primarily comprises stating divine matters into human speech. The messenger god Hermes had to understand and interpret for himself what the gods wanted to say to humans before translating, articulating, explaining and explicating their intentions to humans ${ }^{4}$. Although the verb tends to be used today simply as an act of "interpreting", Gadamer ${ }^{5}$ insists on the sacral origin of the Greek word: Hermes explains the complex meanings of gods' orders in the language that human beings can understand.

2 White, "The Historical," 1207.

3 Richard E. Palmer, Hermeneutics (Evanston: North-Western University Press, 1969), 13.

4 Kurt M. Mueller-Vollmer, "Language, Mind, and Artefact: An Outline of Hermeneutics theory since the Enlightenment," in The Hermeneutics Reader, ed. Kurt Mueller-Vollmer (Oxford: The Continuum, 1985), 1.

$5 \quad$ Hans-G. Gadamer, Truth and Method (New York: Seabury, 1970), 150. 
In the singular, the term hermeneutic refers to the general theory of interpretation dealing with matters of understanding as maintained in the works of scholars such as Heidegger, Schleiermacher and Ricoeur. In the plural, hermeneutics refers to modern and postmodern hermeneutical stances focusing either on the explanation (Erklärung) of the text or on its understanding (Verstehen $)^{6}$.

In theological scholarship, the word hermeneutics is used in theories like feminist hermeneutics, liberation hermeneutics, African hermeneutics, and recently ecological hermeneutics. The coined word refers to a particular theological ideology or doctrinal key influencing and shaping someone's reading of the Bible. For instance, all the cited kinds of hermeneutics assume that all reading and interpretative strategies are "socially, politically and institutionally situated" "They propose to reread and understand the text from the perspective of the marginalised and oppressed groups by searching to discover voices in biblical texts that might have been ignored, suppressed or hidden by established interpretations. The form of ecological hermeneutics adopted in the Earth Bible Project, as we shall see later, is an example of a radical ideological hermeneutics where the biblical text, written by humans, is suspected of reflecting human interests at the cost of non-human members of the earth community.

\section{Ecological hermeneutics as a reading-focus}

Ecological hermeneutics attempts to retrieve the ecological wisdom in biblical traditions as a response to the ecological crisis. At the same time, it tries to reinvestigate, rediscover and renew the Christian traditions in the light of the ecological challenges ${ }^{8}$. This task urges interpreters to go beyond what has commonly been seen as the meaning of the biblical text in order to generate "new possibilities" of understanding biblical texts.

The field of eco-theology/ecological hermeneutics started to emerge in the early 1960s in the writings of Joseph Sittler and Richard Baer, but gained more interest with the publication of Lynn White's article'. Scholars from all the subfields of theology tried to provide an ecological defence to refute White's thesis. The positive aspect of this exegetical effort has been the scholarly attempt

\footnotetext{
6 Johnson T.K. Lim, A Strategy for Reading Biblical Texts (New York: Peter Lang, 2002), 16.

${ }^{7}$ Hillary Marlow, Biblical Prophets: Contemporary Environmental Ethics (New York: Oxford University Press 2009), 85.

8 Ernest Conradie, "What on Earth is an Ecological Hermeneutics? Some Broad Parameters," in Ecological Hermeneutics: Biblical, Historical and Theological Perspectives, ed. Horrell, D G, Hunt, C \& Southgate, C (New York: T\&T Clark, 2010), 295.

9 Marlow, "Biblical," 82.
} 
to demonstrate that biblical texts offer ecological wisdom, generally hidden or implicit, that can contribute to re-evaluate human relationship towards nature ${ }^{10}$.

In fact, the rise of ecological readings attests that biblical texts have been subject to systematically distorted forms of understanding. As a new key reading perspective on the text, ecological hermeneutics offers two critiques: "a Christian critique of the cultural habits underlying ecological destruction, and an ecological critique of Christianity" 11 . In her analysis, Reuther 12 confirmed that the earth devaluation that is attached to Christian tradition is deeply rooted in the ancient Near Eastern patriarchal domination of the priestly and warrior-king's control over women, land, animals and slaves that are property of the powerful male. It is this ideal that will be embedded in most of ecological hermeneutics.

\section{FACTORS LEADING TO THE RISE OF ECOLOGICAL HERMENEUTICS}

\section{The ecological crisis}

This sub-section does not intend to describe the issues about the ecological crisis, which can be found in good scientific resources of the IPCC, WMO and UNEP. This point needs to assess the ecological crisis as one of the factors that lead the rise of ecological hermeneutics in biblical studies. Habel ${ }^{13}$ explains that the complexity of the current ecological crisis has stimulated the rise of a new Earth $^{14}$ awareness where all forms of life are seen as endlessly dependent on the complex relationships that allow life to flourish on Earth. For Limburg, the cosmic crisis has challenged that "It is time for the churches to think about what the Bible says about our connectedness to the natural"

Through greed, self-interest, ignorance and injustice, humans deliberately cause devaluation and disfiguration of God's creation. Words such as ecocide, ${ }^{16}$ geocide or biocide are now employed to name the great extinction of species and

10 David G. Horrell, "The Ecological Challenge to Biblical Studies," Theology 112 (2009): 165.

11 Ernest Conradie, "Towards an Ecological Biblical Hermeneutics: A Review Essay on the Earth Bible Project," Scriptura 85 (2004):126.

12 Rosemary R. Ruether, "Eco-Feminism: The Challenge to theology," in Christianity and Ecology: Seeking the Wellbeing of Earth and Humans, eds. Hessel, D T \& Ruether, R R (Cambridge: Harvard University Press, 2000), 98.

13 Norman C. Habel, "Introducing the Earth Bible," in Reading From the Perspective of Earth, ed. Norman C. Habel (Sheffield: Sheffield Academic Press, 2000), 26.

14 For Habel, the word Earth is a personal name, and thereby must not be articled.

15 James Limburg, "The Responsibility of Royalty: Genesis 1-11 and the Care of the Earth," WW 11/2 (1991): 129.

16 The words such as ecocide, geocide and biocide refer to adverse alterations, often irreparable, to the environment. See William Schabas, Genocide in International Law: The Crime of Crimes (New York: Cambridge University Press, 2009), 235. 
ecosystems that are supposed to contribute to the ecological balance. ${ }^{17}$ Moltmann (1985:xi) argued that "the earth crisis challenges us to read the Bible afresh and ask whether the biblical text itself, its interpreters - or both - have contributed to this crisis".

Yet, biblical texts were written in the context that knew nothing about modern problems such as air pollution, ecological crisis, global warming. However, since several critics showed the religious tradition's potential to shape human attitudes towards nature, the importance of re-examining biblical texts has interested theological scholarship hoping to offer spiritual and ethical power for ecological awareness that no secular discipline can do.

Therefore, the ecological crisis has led not only to the fact that Christianity could and should make an important contribution to a more adequate understanding of the role of humanity towards nature, but also led to the need for a critical re-examination of the Christian faith itself ${ }^{18}$. Tutu concluded that we cannot leave the task of resolving the earth crisis to scientists. For him, "since we contributed to the problem, we are also part of the solution that is to utilise the forces that have created this crisis and the resources within our traditions that can motivate us to resolve the crisis"19.

\section{Lynn White's thesis}

More than fifty years ago, Lynn White wrote the famous article entitled "The historical roots of our ecological crisis" where he deplored that Christianity bears a huge burden of guilt for having established a dualism between humans and nature. For him, Christianity insisted that it is God's will for humans to exploit and rule over nature for their benefit, and thereby made possible today's conquest of nature, causing the ecological crisis. ${ }^{20}$

Lynn White's article has served as a provocative stimulus. It is probably the most cited source in eco-theological debates. It has been viewed as a watershed publication, similar to Luther's 95 theses at the time of the Reformation. ${ }^{21}$ Many early contributions were harsh criticisms of White's article. Some evangelical scholars treated White's argument as some kind of final

17 Elisabeth A. Johnson, "Losing and Finding Creation in the Christian Tradition," in Christianity and Ecology: Seeking the Wellbeing of Earth and Humans (Cambridge: Harvard University Press, 2000), 15.

18 Conradie, "Towards an Ecological," 125.

19 Desmond Tutu, "Foreword," in Reading from the Perspective of Earth (Sheffield: Sheffield Academic Press, 2001), 7.

20 White, "The Historical," 1207.

21 Paul Santmire, Nature Reborn: The Ecological and Cosmic Promise of Christian Theology (Minneapolis: Augsburg Fortress Press, 2000), 11. 
solution for humanity, according to which the numbers of humans on the earth would have to be reduced in order to preserve other species ${ }^{22}$.

White deplored the dualistic thoughts embedded in the Christian interpretations. Earlier, Hegel viewed the history of religion as a dialectical process passing from the religion of nature (pantheism) to the absolute/revealed religion via the religion of spiritual individuality. For him, the Ancient Near Eastern cosmogonies fit into the first stage, while the Israelite religion stands at the second phase dividing the world between the natural and the spiritual. The third (Christian religion) de-divinised and devalued nature on its way towards a religion of humanity. ${ }^{23}$

From this perspective, White ${ }^{24}$ claimed that Bible traditions erased the ancient mythological cosmogonies with their cyclical views of time and their animistic sacralisation of nature, and established a dualism between humans and nature. Despite his criticism of Christianity, Lynn White ${ }^{25}$ acknowledged that: "More science and more technology are not going to get us out of the present ecological crisis until we find a new religion, or rethink our old one".

In this statement, White recognises the potential of biblical traditions to tackle the crisis. In this sense, he identified St Francis as the 'patron saint for ecologists', because Francis tried to depose humans from their dominion over creation and set up a democracy of all God's creatures ${ }^{26}$. Francis' sense of solidarity with the whole creation is regarded as something that, in White's view, can help us to discover the values we need to deal with nature.

\section{The marginalisation of nature in biblical exegesis}

For years, Biblical theology simply meant history of salvation (in German: Heilsgeschichte) where creation stories were read not for their own sake, but for their usefulness for Israel's people (humans) and Christian belief. In his famous essay on "the theological problem of the Old Testament doctrine of creation", Gerhard von Rad subordinates creation/nature to the history of human redemption. He stated that, the Yahwistic faith of the Old Testament is based on

\footnotetext{
22 Santmire, Nature reborn, 12.

23 Friedrich Hegel, Lectures on the Philosophy of Religion: Introduction and the Concept of Religion, Vol.1, (Berkeley/Los Angeles/London: University of California Press, 1984), 1983-184.

24 White, The Historical, 1205.

25 White, The Historical, 1207.

26 White, The Historical, 1206.
} 
the notion of election, and therefore is primarily concerned with the redemption of humans, and of Israel in particular. ${ }^{27}$

In Von Rad's theology, non-human beings are secondary. For him, "the creation of the world is not to be considered for its own sake, or as of value in itself, but rather it performs only an ancillary role to stimulate faith in the redemption: it is a brilliant foundation for the message of salvation" 28 . In this sense, the aim of creation stories is not faith in creation, but faith in salvation and election of Israel. By this statement, Von Rad lowered nature. For him, Genesis 1-11 must be read as a prologue to the salvation history of God's people ${ }^{29}$. One can read in his view a dichotomist presupposition between redemption and creation, human domain and the world of non-human, and that the whole Bible is about human salvation.

In this view, the redemption of humans and of Israel in particular, surpasses all other interests and thereby, the realm of non-human beings appears as background and becomes less important. The creation accounts serve the purpose of understanding the history of salvation, rather than describing the universe for its own sake ${ }^{30}$. Nature is not only separated from human history, but it is also viewed as secondary, an object and inferior to it.

This conception offered the basis for many later publications about nature/creation in biblical texts. Like Von Rad, Wright ${ }^{31}$ and Anderson maintain that the creation motif is not presented in the Bible as an independent doctrine but it is inseparably related to the basic story of Israel in which God is presented as the actor and the redeemer. For Anderson ${ }^{32}$, the first thing that Israel said was not "in the beginning God created the heavens and the earth", but rather, "in the beginning Yahweh created Israel to be his people and allotted him a task and a future in his purpose".

Consequently, Christians only thought about themselves and the salvation of their souls. Their mission frequently focused on saving souls for heaven,

27 Gerhard von Rad, "The Theological Problem of the Old Testament Doctrine of creation," in The Problem of The Hexateuch and Other Essays (London: SCM Press, 1984), 137.

28 von Rad, "The theological," 138-139.

29 von Rad, "The theological," 144.

30 Theodore Hiebert, The Yahwist's Landscape: Nature and Religion in Early Israel (New York/Oxford: Oxford University Press, 1996), 5.

31 Ernest Wright, God Who Acts: Biblical Theology as Recital (London: SCM, 1952), 38.

32 Bernhard W. Anderson, From Creation to New Creation (Minneapolis: Fortress Press, 1994), 5. 
instead of saving the earth for living, and left the cause of the earth to scientists and ecologists. ${ }^{33}$

It was only later scholars who made some efforts to recover a prominent role for creation or nature in biblical studies. Westermann ${ }^{34}$, for instance, takes some steps against Von Rad by declaring that the creation accounts do not have a historical purpose, rather they are a witness to God's ongoing creative work in every present moment. Genesis does not describe a thinker's investigation about his history, but someone endangered by his surroundings: "the background of creation stories was an existential interest, rather than an intellectual inquiry" ${ }^{\prime 35}$.

Here starts the awareness that human history should not be contrasted to nature since 'human activity is an integral part of the history of a particular environment, and the environment embodies the history of a community ${ }^{36}$. Schmid further explains this idea showing that creation/nature in Israel is mostly interpreted in terms of the continuing order, which is similar to the Egyptian $m a$ 'at referring to justice and world order built by God into the network of creation $^{37}$. Therefore, wherever humans practise righteousness in the sociopolitical spheres, that act promotes the proper integration of social and cosmic orders. In the Old Testament, justice, politics and nature are interrelated as part of one comprehensive creation order; the unrighteousness of human beings results in adverse consequences against the entire creation.

Although Westermann and Schmid did not write for an ecological purpose, their arguments can be seen as precursors of ecological awareness in biblical exegesis. Before analysing the prevailing forms of ecological hermeneutics, I wish to mention another factor at the foundation of ecological hermeneutics: the anti-ecological eschatological reading.

\section{Anti-ecological eschatological readings}

Biblical texts on the imminent end of the world are also among the factors that motivated ecological hermeneutics. Several biblical texts announce the future cosmic destruction which will occur on the coming day of God's judgement and

33 Norman C. Habel, "The Origins and Challenges of an Eco-justice Hermeneutics," in Relating to the Text. An Interdisciplinary and Form-Critical Insights on the Bible, eds. TJ Sandoval and C Madolfo (New York: T\&T Clark, 2003), 294.

34 Claus Westermann, Creation (London: SPCK, 1974), 11.

35 Westermann, Creation, 11.

36 Willie van Heerden, "Taking History Seriously in our Understanding of How we Humans Value the World in which we Live (paper presented at the Conference of the Sustainability Institute on "Christian Faith and the Earth: Respice et Prospice', Stellenbosch 9 August 2012), 5.

37 Hans H. Schmid, "Creation, Righteousness, and Salvation: Creation Theology as the Broad Horizon of Biblical Theology," in Creation in the Old Testament, ed. Bernhard W. Anderson (Philadelphia: Fortress Press, 1984), 106. 
salvation of believers (Jl 1:15; Am 5:18-20; 1 Th 5:22). Other texts insist that the final day of salvation will be preceded by catastrophes on the earth (Mt 24; Mk 13:8, 24-25) before believers go up to meet the Lord in the air (1 Th 4:16-17).

These texts are often used to teach that the 'real' ecological disaster comes, not from global warming, but rather from the fire of judgement, which God will bring upon the earth. Thus, an online popular evangelical article entitled "Beware of Global warming and 2 Peter 3" writes the following:

While it is true that we are all stewards of the earth and should thus take care of it, we should also be aware of the fact that the 'heavens and earth which are now' are being prevented from being destroyed by the Word of God (2 Peter 3:7). God will one day destroy the earth with the fire of judgment, and this is the warning that Christians must take to those who are lost, in order that they [might] be saved through the obedience of the Gospel. ${ }^{38}$

Therefore, some eschatologists negate any motivation for preserving the earth since the disasters on the earth are the signs that the return of Jesus is near. For them, working to preserve the earth is not only pointless, it is working against God's eschatological purposes - and thus for Satan' ${ }^{39}$. In other words, since the destruction of the natural universe must happen before the end, there is no need to care for earth. With this belief in mind, Christians would passively accept ecological disasters knowing that it is God's will.

This kind of eschatological expectation has a significant impact, albeit indirect, on the ecological agenda because these beliefs consider natural disasters as indicators of the imminent end. With this kind of perception, the implication would be that the present earth is unimportant; it is to be abused, exploited and even destroyed with impunity. This belief also reinforces Christian hope on the rescuing of the elect from a doomed earth, rather than (say) on the liberation and renewal of all creation ${ }^{40}$. One will therefore detect that:

[The] growing popularity of eschatological and apocalyptic stories ... give little or no motivation for care of the earth ... once the prerogative

38 Spencer Strickland, "Beware of Global Warming! (2 Peter 3:6-7)", Saving Earth on human at a time: my people are destroyed for lack of knowledge, 7 August 2008. http://jeremiahdanielmccarver.wordpress.com/2008/08/07/beware-of-global-warming2-peter-36-7/

39 David G. Horrell, The Bible and the Environment: Towards a Critical Ecological Biblical Theology (London, Oakville: Equinox, 2010), 16.

40 Paul Boyer, When Time Shall Be No More: Prophecy Belief in Modern American Culture (Cambridge: Harvard University Press, 1992), 34. 
of Darbyites and Sectarians, [it] is now popular and widespread in the USA, and in other American influenced evangelical movements. ${ }^{41}$

Although such eschatological views had little interest in academic scholarship, they deserve our attention, since they still have a popular influence in some evangelical and fundamentalist areas, notably in the USA and in Africa. Lynn White and sociologists have made a link between such belief and antiecological behaviours and practices. ${ }^{42}$ President Donald Trump's position about environmental treaties is an example. While his predecessor Barack Obama, a more liberal politician, added climate change to the list of threats in 2015 saying it was an "urgent and growing threat", Trump repealed it from his list and withdrew from the Paris agreement on climate ${ }^{43}$. For him, the Paris agreement undermines US sovereignty and economic growth. Although his argument is said to be motivated by US sovereignty and economic interest, who knows that Trump's decision is somehow rooted in the evangelical anti-ecological thought?

This is not new in the US political sphere. A historical example is Watt, President Ronald Reagan's Secretary of the Interior. On February 5, 1981, in response to a question about keeping resources for future generations, Watt declared: "I do not know how many future generations we can count on before the Lord returns" 44 . Differently stated, since Jesus is coming back, and as when he returns everything will be destroyed, the issue of care for the earth is secondary.

\section{APPROACHES TO ECOLOGICAL HERMENEUTICS}

\section{Introduction}

In response to the above challenges, the discipline of eco-theology has developed diverse and creative thoughts about the relationship between humans and nonhuman members of the earth community. However, not all ecological reflections used biblical exegesis to address ecological issues ${ }^{45}$. It is partly for this reason

41 Nicola H. Creegan, "Theological Foundations of the Ecological Crisis," Stimulus 12/4 (2004): 33.

42 Douglas L. Eckberg and Jean Blocker, "Christianity, Environmentalism, and the Theoretical Problem of Fundamentalism," JSSR 35 (1996): 348.

43 Jilian Kestler-D'Amour, "US president is rolling back the country's efforts to fight climate change. Here's a look at what he has done so far", One year under Trump: Attack on Climate change fight, 17 January 2018. https://www.aljazeera.com /news/2017/12/explained-donald-trump-attack-environment-171203184502851.html

44 Steven Bouma-Prediger, For the Beauty of the Earth: A Christian Vision for Creation Care (Grand Rapids: Baker Academic, 2001), 71.

45 We may mention the Gaia eco-philosophy in which mother-earth is viewed as a self-regulating, self-sustaining entity, which continually adjusts its environment in order to support life. See Anne Primavesi, From Apocalypse to Genesis: Ecology, Feminism and Christianity (Minneapolis: Fortress Press, 1991), 92. 
that biblical scholars get involved in the ecological readings of the Bible. In the following sections, I give an overview of four modes of ecological hermeneutics prevailing in current biblical studies.

\section{Recovering ecological wisdom from the Bible}

This hermeneutic is also called the "apologetic reading" attempting to respond to Lynn White's accusation by showing that biblical traditions are rather ecofriendly. This hermeneutical approach was named by Watson as a "strategy of recovery" 46 of the eco-friendliness of biblical texts. The readings of recovery argue that the Bible is not itself the problem, but the problem came through the acts of later interpreters, who obscured and distorted the positive meaning of the original $^{47}$. The intention is to rescue the Bible from the charge that biblical texts endorse an anthropocentric vision legitimising utilitarian and abusive attitudes towards the natural world.

Previously, Barr delivered a lecture about the "ecological controversy and the Old Testament" in which he deliberately reacted to Lynn White. He argued that the Hebrew verbs used in Genesis 1:26-28 are not as strong as often suggested by eco-theologians. He confirmed that biblical traditions of creation are not about the exploitation of the earth but its protection and preservation ${ }^{48}$. Bauckham continues that the human-centred vision is not an intrinsic feature in Genesis 1:26-28, but emerged only when it was read through the lens of nonbiblical Greek thoughts and then much later in the context of Renaissance philosophy of human strength and progress ${ }^{49}$.

The recovery exegetical task consists in uncovering such ecological potential and defends Christianity against its detractors. Santmire ${ }^{50}$ defined this tendency as "apologetic" consisting of defending Christian traditions by underlining their "positive ecological implications". For this reason, Biblical scholars selected a wide overview of Old Testament and New Testament texts favouring the insights of stewardship or caring for the earth. Among them, a few green texts are given below: the creation texts of Genesis 1-2, the theme of the covenant (Gn 6-9), the Sabbatical laws (Lv 25), Job 37-39, some of the Psalms

46 The wording 'reading of recovery' and 'reading of resistance' are borrowed from F. Watson, "Strategies of Recovery and Resistance: Hermeneutical Reflection on Genesis 1-3 and its Pauline Reception," JSNT 45 (1992): 81-82.

47 David G. Horrell and Christopher Southgate, "Appeal to the Bible in Ecotheology and Environmental Ethics: A Typology of Hermeneutical Stances," SCE 21/2 (2008), 221.

48 James Barr, "Man and Nature. The Ecological Controversy and Old Testament," BJRL 55 (1972), 30.

49 Richard J. Bauckham, God and the Crisis of Freedom: Biblical and Contemporary Perspectives (Louisville, Kentucky: John Knox, 2002), 141.

50 Santmire, Nature reborn, 7. 
$(8,19,24,98,104)$, some prophetic texts such as Isaiah 9-11, 40f, 65 and Ezekiel 36. Attention has been given also to some of Jesus' speeches (e.g. in Mt 6:28-30, 10:29-31), Romans 8:18-23, Colossians 1 and Revelation 21-22.

Sider ${ }^{51}$ concluded that anyone who thinks that non-human creatures do not have an intrinsic value in biblical texts, forgets that God feeds the birds and clothes the lilies (Mt 6:26-30), and that after the flood God makes a covenant, not just with humans (Noah and his family), but also with non-human beings ( $\mathrm{Gn}$ 9). Accordingly, Wright ${ }^{52}$ affirmed that the eschatological language in Mark 13 does not mean the literal 'end' of the present space-time universe, but an 'end' of the present 'world order', since most of Jews of this time longed for the renewal, not the desertion, of the present space-time world as a whole.

More significant is the project of 'The Green Bible' edition. In the project, the so-called green texts are intentionally selected in 'green ink' to include every possible passage or occurrence of relevant words, as well as the texts demonstrating how God and Jesus interact with, and are intimately involved with, all of creation. Attention is paid to the way the elements of creation are interdependent, on how nature responds to God, and the way humans are appointed to care for all God's creation. Yet, the publication has the value to contribute towards a growing ecological awareness and the greening of the churches.

\section{Resisting biblical texts in favour of the earth}

This approach is fundamentally earth-centric rejecting both the anthropocentric reading that is susceptible to species extinction, and the stewardship model considering humans as inevitable link between the Creator and other living beings. Its supporters believe that Earth does not necessarily need the participation of human beings to solve its problem, because Genesis 1 shows that nature existed before humans. On this issue, a Roman Catholic scholar declared:

Our best procedure might be to consider that we need not a human answer to an earth problem, but an earth answer to an earth problem. The earth will solve its problems, and possibly our own, if we will let the earth function in its own ways. We need only listen to what the earth is telling us. ${ }^{53}$

The most coherent example of this approach is the ecological hermeneutics developed in The Earth Bible Project. The works of the Earth Bible

51 Ronald J. Sider, "Biblical Foundation for Creation Care," in The Care of Creation: Focusing Concern and Action, ed. RJ Berry (Leicester: Inter-Varsity Press, 2000), 47.

52 NT Wright, New Heavens, New Earth: The Biblical Picture of Christian Hope (Cambridge: Grove, 1992), 310.

53 Thomas Berry, The Dream of the Earth (San Francisco: Sierra Club Books, 1988), 35. 
Project stands at least as the most significant example of ecological readings of biblical texts. Since 2000, The Earth Bible Project has published five volumes offering several insights for "Readings from the Perspectives of Earth". More significant is the newly published volume entitled "Earth Bible commentary series" that is, in the author's words, "the natural extension of the Earth Bible Series published between 2000 and 2002" ${ }^{4}$. In this exegetical volume, Habel employs his ecojustice ecological hermeneutics to comment on Genesis 1-11.

In both series, Habel argues for new reading lenses in which the interpreters are invited "not to reflect about Earth in the text, but rather to reflect with and within Earth and see things from the perspective of Earth". ${ }^{55}$ The interpreter reads the text not as steward over creation, but as a kin, a relative and member within the earth community, sharing with it benefits and problems.

This approach is similar to feminist writings in which biblical texts are exposed as inherently patriarchal and promoting sexist values against women. The works in the project carefully showed how many texts of the Bible devalue Earth and the Earth community. Authors in the Earth Bible series partly agree with White at least, and propose to resist against biblical texts that depict humans as superior rulers of the world and the earth as victim. One of the authors writing in The Earth Bible Project on Genesis 1:26-28 and the dominion mandate, has asserted that the Bible has few, if any, positive insights for the future of the planet. $^{56}$

This radically resistant statement resulted from her analysis based on a threefold hermeneutics of suspicion, identification and retrieval on the text. The suspicion task suspects that biblical texts, written by humans, reflect the primary interests of human beings, their welfare, their relationship to God and their personal salvation ${ }^{57}$. The reader keeps a critical suspicion towards the anthropocentrism of biblical writers as well as their later readers. He/she identifies himself with the non-human characters in the text and retrieves or tries to recover the voice of Earth where this is silenced or opposed by the explicit perspective of the text.

Alongside this hermeneutical process of suspicion, identification and retrieval, the Earth Bible Project has developed six ecojustice principles ${ }^{58}$ acting as ethical guide and standard canon by which biblical texts are measured. Like

54 Norman C. Habel, The Birth, the Curse and the Greening of Earth: An Ecological Reading of Genesis 1-11 (Sheffield: Sheffield Phoenix Press, 2011, ix.

55 Habel, "Introducing the Earth Bible," 34-35.

56 Veronica Brady, "Preface," in Reading from the Perspective of Earth, ed. Norman C. Habel (Sheffield: Sheffield Academic Press, 2000), 13.

57 The Earth Bible Team, "Guiding Ecojustice Principles," in Reading from the Perspective of Earth, ed. Norman C. Habel (Sheffield: Sheffield Academic, 2000), 39. 58 For all six ecojustice principles, see The Earth Bible Team, "Guiding," 38-53. 
the interests of women had priority over both misogynist texts and social structures, these six eco-justice principles are employed as to judge both the validity of the text and contemporary culture. The key-task is to discern whether the text favours the earth, or if the text is in conflict with any of the following ecojustice principles:

1. The Principle of Intrinsic Value: the universe, Earth and all its components have intrinsic worth/value.

2. The Principle of Interconnectedness: Earth is a community of interconnected living things that are mutually dependent on each other for life and survival.

3. The Principle of Voice: Earth is a subject capable of raising its voice in celebration and against injustice.

4. The Principle of Purpose: The universe, Earth and all its components are part of a dynamic cosmic design within which each piece has a place in the overall goal of that design.

5. The Principle of Mutual Custodianship: Earth is a balanced and diverse domain where responsible custodians can function as partners, rather than rulers, to sustain a balanced and diverse Earth community.

6. The Principle of Resistance: Earth and its components not only differ in terms of their injustices at the hands of humans, but actively resist them in the struggle for justice.

According to the Earth Bible Project, these principles were deliberately formulated in non-theological and non-biblical terms in order to facilitate dialogue with biologists, ecologists, non-Christian religions, and scientists who may not function with God or God's creation as an a priori assumption ${ }^{59}$. Thus, the specific religious terms such as God or creation are simply avoided in accordance with secular movements and natural science. The Team suggests that this ideal allows the reader or the interpreter to focus on Earth itself as the object of investigation in the text, rather than on Earth as God's creation or property. Probably, the following form of resistance rose to resist against this idea and any ecological reading of biblical texts in general.

\section{Resisting ecological focus in favour of biblical authority}

This approach is exactly the opposite of the ecological hermeneutics of the Earth Bible series. Biblical texts are seen as non-negotiable loci of authority that no contemporary reality can challenge. Environmentalism is therefore rejected for its criticism character, which is associated with secularism, and therefore a mask of Satan. Cumbey ${ }^{60}$ argued that expressions such as friends of Earth,

\footnotetext{
59 The Earth Bible Team, “Guiding," 38.

60 Constance Cumbey, The Hidden Dangers of the Rainbow: The New Age Movement and our Coming Age of Barbarism (Lafayette: Huntington House, 1983), 167.
} 
stewardship, earth-keeping or planetary awareness belong to the New Age movement, ${ }^{61}$ which is itself a mask of satanic influence.

In addition, adherents are keenly committed to the text of Revelation 13 where it is stated that "God will create a new heaven and a new earth". In this regard, any actions of friendship with the world/earth are unbiblical since God is going to make all things new, rather than redeeming nature alongside humans ${ }^{62}$. For this reason, Cumbey opposed any interest in the word stewardship, for instance, since it is claimed by great figures of anti-Christianity. In her own words, she declared:

Christians are urged to support internationalism in the interests of stewardship [of the world/earth]. Of course, what they are not told is that the people heading up the internationalist efforts - Donald Keys, David Spangler, and the rest of the Planetary Citizens' gang - are open Luciferians. Once the Structures are established - even if St. Francis of Assisi [the patron saint for ecologists] were [sic] running them - they are available for takeovers by those interests wishing to establish the one-world government of the antichrist as foretold in Revelation $13 .^{63}$

Although such anti-ecological thoughts are hardly represented within academic and theological scholarship, they deserve our consideration since they have gained popular influence in some evangelical and fundamentalist areas, particularly in the USA and Africa. Some fundamentalists had literally quoted 1 John 2:15-17 to warn against the love/care for the natural world:

Do not love the world or the things in the world. The love of the Father is not in those who love the world; for all that is in the world - the desire of the flesh, the desire of the eyes, the pride in riches comes not from the Father but from the world. And the world and its desire are passing away, but those who do the will of God live forever (NRSV).

61 The New Age movement is an umbrella term referring to a variety of people, organisations, events, ideas and practices. Sociologically, it is not a centrally organised movement with one human leader. Rather it is a collection of like-minded people and groups all desiring a spiritual and social change that will usher in a New Age of selfactualisation (see Douglas R. Groothuis, Confronting the New Age: How to Resist a Growing Religious Movement (Downers Drove: Intervarsity Press, 1988), 18.

62 Loren Wilkinson, "New Age, New Consciousness, and the New Creation," in Tending the Garden, ed. Wesler Granberg-Michaelson (Grand Rapids: Eerdmans, 1987), 26.

63 Cumbey, The hidden, 166. 
With such popular ecological beliefs in mind, anti-ecological readers of the Bible made six provocative principles in reaction to those of the Earth Bible project. They call them "six Biblicist eschatological principles" as listed below: ${ }^{64}$

1. The principle of imminent cataclysm: Earth is headed for disaster which will happen sooner rather than later;

2. The principle of disconnectedness: we humans do not have to share or feel responsible for Earth's fate. Salvation is for humans, not for Earth;

3. The principle of inevitability: there is nothing we (humans or Earth) can do about it;

4. The principle of transcendence: what really matters is the next world. This world is ephemeral and ultimately unimportant compared to the better future existence.

5. The principle of sovereignty: God is in ultimate (even direct) control of all this.

6. The principle of self-interest: God will rapture 'believers' out of this mess at the End.

These principles clearly reflect a popular human-centred eschatological interpretation firmly rooted - consciously or not - in the beliefs and practices of today's fundamentalist Christians. Believers must consider themselves as pilgrims on the earth, and long for the forthcoming new earth. There is no need to care about this earth since it is God's will to destroy it for the salvation of believers.

\section{Revisionist ecological hermeneutics}

Revisionist readings may be situated between recovery and resistance readings. More than the hermeneutics of recovery or resistance, revisionist readings do not aim to defend (recovery) or to reject (resistance) the classical Christian tradition, but to "re-claim" it historically in its ecological and cosmic fullness ${ }^{65}$. The supporters of this approach define it not only as an innovative orthodox reading, but also as the reformation and reconfiguration of the theological reflection on ecological and related global issues. ${ }^{66}$

Revisionists claim the dynamics of the classical Christian tradition that constantly contain self-criticism. Current readers recognise that earlier interpreters did not share our ecological threats. This might have helped to reinforce the anthropocentrism aspect of the theological tradition. However, it is also possible to find potentially fruitful interpretative perspectives in previous engagements with the biblical texts.

64 Horrell, The Bible and the environment, 18.

65 Santmire, Nature reborn, 10.

66 Horrell and Southgate, "Appeal to the Bible," 233. 
Santmire regarded this interpretative analysis as the "rebirth of nature" within the classical Christian tradition. Rather than simply defending or rejecting the tradition, revisionist readers claim to reshape ecologically the same tradition that has been largely interested by the issue of human salvation at the cost of non-human earth members. This is the ecological hermeneutics developed by the Exeter Project in the UK.

Unlike Reformation hermeneutics that basically involve anthropocentric readings of creation and salvation texts, revisionist readers claim to rediscover, to identify, to revise and to celebrate the cosmic promise of Biblical texts. ${ }^{67} \mathrm{In}$ this sense, revisionists claim to 're-envision' the classical Christian tradition for serving the worship, the teaching and the public witness of the church in current ecological and existential crisis. ${ }^{68}$

On this interpretative model, Santmire proposes 'the future and the fullness thereof as a revitalised interpretative construct' of the Saint Augustinian notion of 'first things and last things.' In this sense, Biblical texts are interpreted through the ecological lenses of the universalising hermeneutic of the future and the fullness thereof, attentive to the land of fecundity and justice, on the one hand, and the fecundity of the earth on the other hand. ${ }^{69}$

Indeed, revisionists offer valuable readings in trying, neither to defend Christian tradition nor to reject it, but to reform it ecologically. However, the main problem is what should count as orthodox? Also, the interpretative framework proposed by Santmire will oblige the interpreter to read every text with a universal and eschatological perspective. I think biblical writers intended neither to resolve universal matters, nor the questions in future, but firstly their readers' daily challenges.

\section{Eco-feminist and African eco-theologians}

Ecological feminism is a kind of convergence of ecology and feminism into a new social theory and political movement ${ }^{70}$. The movement emerged in the early 1970s mostly in North America, while the word eco-feminism itself was coined in 1974 by the French feminist Françoise d'Eaubonne to raise women's potential for an ecological revolution. As such, Ecological feminism offers an ethical

\footnotetext{
67 Santmire, Nature reborn, 9.

68 Santmire, Nature reborn, 9.

69 Santmire, Nature reborn, 36.

70 Val Plumwood, Feminism and the Mastery of Nature (New York: Routledge, 1993), 39.
} 
framework, which takes seriously links between the rule of men over women and the oppression of nature ${ }^{71}$. In other words,

Eco-feminism brings together elements of the feminist and the green movement, while at the same time offering a challenge to both. It takes from the green movement the concern about the impact of human activities on the non-human world and from feminism the view of humanity as gendered in ways that subordinate, exploit and oppress women $^{72}$.

Eco-feminism is then represented as the symbolic and social connection between the oppression of women and the domination of nature. In other words, eco-feminism brings together these two entities in their deep explorations, since they are all objects of male dominion and power both in cultural ideology and in social groups. The idea is that over the course of time, male dominion over women came to determine human life and cultures about all kinds of relationships, including those of people with the rest of the natural world ${ }^{73}$.

In theological scholarship, eco-feminists explore various ways in which Christian traditions have contributed to establish women-nature social construct and the rupture between culture and the natural world. Eco-feminists confirm that women and nature have been assimilated to the rank of objects that lack respect and ethical responsibility. In what she coined as "ecobosadi"74 reading of the so-called androcentric Psalm 127:3-5, Masenya ${ }^{75}$ conveys that African Mothers and Earth suffer a common abuse from the male drive for reproduction.

71 Karen P. Warren, "The Power and the Promise of Ecological Feminism," in Reading in Ecology and Feminist Theology, ed. Mackinnon, M H \& McIntyre, M (Kansas City: Sheed \&Ward, 1995), 172.

72 Mary Mellor, Feminism and Ecology (New York: New York University Press, 1997), 1.

73 Robert B. Fowler, The Greening of Protestant Thought (London: North Carolina University press, 1995), 124.

74 Bosadi is a word from Sesotho (one of local South African languages), and relates to something like femaleness (mosadi in Sesotho means woman/mother). Therefore, the South African Old Testament scholar Masenya used this term to indicate the distinctiveness of her approach, which is mostly committed to address issues affecting African women, and Earth in extension. For her, in acknowledging the interconnection between women, children and the land, one's focus turns from filling Earth to preserving Earth as part of our identity (see Madipoane J. Masenya, "An Ecobosadi Reading of Psalm 127:3-5," The Earth Story in the Psalms and the Prophets, ed. Norman C. Habel (Sheffield: Sheffield Academic Press, 2001), 222.

75 Masenya, “An Ecobosadi," 222. 
Biblical eco-feminists argue that Genesis 1:26-28 is a clear locus of the patriarchal power relations of dominion. ${ }^{76}$ As such, revisionist eco-feminists argue for a kind of redefinition of the basic doctrine of creation in relation to the oppressed. The ideal is not replacing man dominion by female-nature power, but resisting the male supremacy embedded in biblical traditions. ${ }^{77}$ As Yvone Gebara $^{78}$ noted, "the Bible is not the Word of God, but the words of humans about God, and as such it reflects not forcibly the point of view of God on nature, but the ones of the writers, who were mostly male."

By contrast, radical eco-feminists argue that Christian traditions of creation must be deconstructed, resisted and rejected altogether and be replaced by another theory that is more eco-friendly. Rosemary Radford Ruether ${ }^{79}$ said that this resistance must be done in all the spheres of the Christianity because there cannot be solution to the ecological crisis in a society that is basically defined in the interest of male dominion over others. The liberation of women and nature can only be attained by a radical change in the prevailing patriarchal and eco-social conception of the world.

\section{Eco-theological voices from Africa}

Earlier African voices were strategies of recovery trying to defend the Bible against the accusation of Lynn White. In his pioneering article on ecological hermeneutics in South Africa, Loader declared "it is wrong to blame biblical faith for this [ecological crisis], and in this sense, White's indictment is wrong (...): neither Christian faith itself nor biblical faith, but the interpretations and emphases of modern Christianity, are to blame." ${ }^{80}$ Put simply, the problems lie, not in the texts themselves, but in the traditions of their later interpretation. Van Dyk, another African scholar, has rather adopted a resistance tendency. For him, the Bible "has very little (if anything) to say on ecological and conservation matters." $" 1$

76 Heather Eaton, "Ecofeminist Contribution to an Ecojustice Hermeneutics," Reading from the Perspective of Earth, ed. Norman C. Habel (Sheffield Academic Press, 2000), 55.

77 Primavesi, From Apocalypse, 92.

78 Yvonne Gebara, "Cosmic Theology: Ecofeminism and Panentheism," in Readings in Ecology and Feminist Theology, eds. Mackinnon, M H \& McIntyre (Kansas City: Sheed \& Ward, 1995), 209.

79 Ruether, "Eco-Feminism," 115.

80 James A. Loader, "Image and Order: Old Testament Perspectives on Ecological Crisis," in Are we killing God's Earth? Ecology and Theology, ed. Vorster, V S (Pretoria: UNISA Press, 1987), 9.

81 Peet Van Dyk, A Cosmological Interpretation of the Old Testament: Ecological Implications. Paper presented at the 6th AASR conference on 'Religion, Ecology and the Environment in Africa and the African Diaspora' held at the University of Cape Town (Graduate School of Business) from 30 July-2 August 2014, Cape Town. 
Later African interpreters are somehow over-simplistic trying to bring biblical texts to fit with African traditions. Ademiluka, for instance, said that the Leviticus traditions of clean and unclean animals anticipate certain aspects of modern environmental sanitation, especially in Africa where preponderant environmental pollution and frequent outbreaks of communicable diseases prevail $^{82}$. While this kind of reading would help to sensitize our people against common issues, it is not however obvious that Leviticus intended such kind of meaning.

Therefore, Van Heerden developed a more challenging approach in which the text is given its respect while interacting with contemporary issues. In his two recent articles, Van Heerden successfully argued that to address the issue of anthropocentrism of the Bible one needs to turn not to interpretative constructs, but to the Bible itself. He has successfully used the book of Jonah to demonstrate this $^{83}$. For him, the act of textual interpretation must involve three relationships to a text: 1) a problem situation moves the reader to consult the Bible; 2) the reader experiences the text itself as problematic; 3) the text itself offers a response to a problem situation. Van Heerden notes that interpreters limit themselves to the first two, and that is why they end up either in defending of resisting the text. ${ }^{84}$

\section{E CRITICAL ASSESSMENT OF PREVIOUS HERMENEUTICS}

\section{Readings of recovery}

The readings of recovery easily give the impression that ecological wisdom can simply be extracted from any text of the Bible when the text is rightly understood, and that the Bible can be defended against all charges addressed against it. Indeed, recovery-reading strategies supporting the key-concepts of stewardship and caring responsibility have the value of urging humans to love and care for creation. The recovery mode reflects a strong commitment both to ecological values and to the authority of the Bible.

In seeking only to defend biblical texts, this reading fails to acknowledge both the ambivalence and the otherness of biblical texts on which ecological hermeneutics are necessary. One of the problems of readings of recovery is that they give the impression that one may leap from biblical exegesis to contemporary theology without considering the gap that separates the world of

82 Salomon O. Ademiluka, “An Ecological Interpretation of Leviticus 11-15 in an African (Nigerian) Context" Old Testament Essays 22/3 (2009): 531-533.

83 Willie Van Heerden, "Ecological interpretations of the Jonah narrative - have they succeeded in overcoming anthropocentrism?" Journal for Semitics 23/1 (2014): 129.

84 Willie Van Heerden, "Dealing with the history-nature dualism in ecological theology," Journal for Semitics 23/2i (2014): 563. 
biblical texts from our contemporary concerns. ${ }^{85}$ I think, we should acknowledge that biblical texts - written in pre-modern times - contain diverse and ambivalent materials that need critical analysis before their application to our ecological issues.

\section{Reading of resistance in the Earth Bible series}

The reading of resistance of the Earth Bible series offers a strong commitment to ecojustice and a willingness to criticise, resist and even reject and abandon biblical texts oppressing the earth. Yet, the reading offers valuable insights that enable the interpreter to retrieve hidden ecological wisdom that could not be found in traditional reading of the biblical texts.

However, while generating great ecological material, this kind of reading does not sufficiently articulate how such creative and critical interpretation can contribute to re-design a proper biblical ecological theology in which the Bible plays a formative and authoritative role. Interpreters content themselves with proposing an imaginative text in replacement of a so-called "grey-text", a text which is ecologically negative.

Moreover, its six eco-justice principles are ecologically fruitful when the text complies with them. The problem is that the interpretative authority lies not in the Bible or the Christian tradition, but with these principles, regarded as a "small dogmatic", the norms by which the validity of the text is measured ${ }^{86}$. They are radically made with a secular vision avoiding any reference to religious wording. For this reason, when the texts do not comply with them, the hermeneutics of suspicion and resistance is vigorously used to expose and reject their anti-earth focus and propose a new formulation of a text, a product of the reader's imagination. Obviously, such imaginative text does not bear the same power as a new interpretation of biblical texts themselves could do.

\section{Resisting the ecological reading of the Bible}

This resistance is mostly interested in defending the authority of the Bible against any challenges from modern reality, whether ecological, political or womanist interests. The so-called six Biblicist eschatological principles offer eloquent disagreements and even rejection of any ecological interest. We have mentioned this kind of resistance only for its underlying popular influence on evangelical beliefs of contemporary Christians.

The problem of this tendency is that believers are constantly considering themselves as pilgrims on earth and passively experience the ecological degradation. This approach is well established in fundamentalist areas and is

85 Horrell and Southgate, "Appeal to the Bible," 234.

86 Horrell, "The Ecological," 168. 
amplified in our churches sermons that mostly focus on the salvation of human beings. This approach is also not taken seriously in academic circles.

Revisionist readings have the privilege not to abandon or to defend Christian tradition, but to renew the interpretation of the biblical texts in relation to ecological threats. Revisionist reading is somehow cogent for an approach that needs to remain in positive relationship with Christian tradition. The problem is that the reader will probably be submerged by the burden of the so-called tradition and not freely develop an innovative interpretation. In addition, searching to rediscover the 'universal meaning' of biblical texts in the interpretative framework of the 'future and fullness,' gives the impression that each and every biblical text contains the idea of the present and the future.

\section{Eco-feminist readings}

Eco-feminist approaches have the privilege of raising the voice of women and nature as object of male exploitation. In other words, the oppressed women and the abused earth are both read as victims of patriarchy. It is as if the oppression of woman by men is extended towards nature. While this is true in certain situations, it is however not clear how women can be termed as having closer or more empathetic relationship with nature than men. This critic also applies to some African eco-theological voices. This is a matter of critical discussion and reflection.

\section{F TOWARDS A FRUITFUL ECOLOGICAL HERMENEUTICS}

\section{Recognising the otherness of biblical texts}

A fruitful ecological reading must admit that biblical texts were formulated in the world that knew nothing about modern ecological problems. Our confrontation with these texts should recognize their otherness to our world to avoid anachronism. Failure to recognize that would lead to a simplistic ecological reading of the Bible that would "end up seeing things in the text that we want (and need) to see, but things which are not really there" 87.

Therefore, having in front of him/her the outline of current problems, the interpreter must carefully listen to biblical texts that may reveal their character as something unique and different in relation to contemporary ecological questions. ${ }^{88}$ The aim of this reading posture is to direct the reader towards the critical power and relevant stimulus of biblical texts for our questions.

The interpreter would never mix in one mould the biblical statements and his/her current realities. The gap separating the concerns of the modern

87 Esias E. Meyer, "Respect for Animal Life in the Book of Leviticus: How Green were the Priestly Authors?" Old Testament Essays 24/1 (2011): 144.

88 Odil H. Steck 1980:16, World and Environment (Nashville: Abingdon, 1980), 16. 
interpreter and the world of the ancient text is enough to prove this fact. This means that our realities should never dictate the direction of biblical interpretation, but both worlds should remain in constant enrichment dialogue. In the words of Horrell ${ }^{89}$, "a message only emerges when an interpreter makes an attempt to articulate what the text says".

\section{The limits of interpretative constructs}

Interpretation of biblical texts in light of contemporary realities often appeals to what Conradie calls "doctrinal constructs," which I call here interpretative constructs $^{90}$. As the term states, these are simply the constructions of the reader to act as the orientation for his/her interpretation, but they are not intrinsic features in the text. They may be viewed as the fruit of a reading perspective.

In this sense, they play a crucial role in the interpretation and the appropriation of biblical texts. Not only do they provide a strategy to unlock both the meaning of biblical text and current context, but also enable the interpreter to establish a link between the text and current reader's reality. Conradie explains the role of doctrinal constructs in a more comprehensive sense that:

Doctrinal constructs are not only employed to find similarities but to construct similarities, to make things similar, if necessary. The scope of such doctrinal constructs is often quite comprehensive: they purport to provide a clue to the core meaning of the contemporary context as a whole and the Biblical text as a whole. ${ }^{91}$

For instance, the notion of stewardship which is so central in the readings of recovery does not visibly appear in several texts such as Genesis 1 and Psalm 8, and nowhere the Bible expressis verbis says that humans are appointed 'stewards' of creation. For this reason, the term stewardship acts as a construct in an ecological hermeneutics. This should be regarded as a product of interpretation, not something intrinsically contained and to be discovered in biblical texts themselves. The same applies to the six ecojustice principles of the Earth Bible Project. ${ }^{92}$ The six ecojustice principles are the construction of the reader, but not something literally contained in the text.

The main danger of interpretative constructs is the tendency of simplification and harmonisation of the text's meaning to one single aspect. Rather than bringing illumination, they run the risk of harmonising differences when contemporary realities do not cohere with some aspects of biblical texts.

89 David G. Horrell, “The Green Bible: A timely Idea Deeply Flawed,” ExpT 121/4 (2010): 182.

90 Conradie, "What on Earth," 301.

91 Ernest M Conradie, "The Road towards an Ecological Biblical and Theological Hermeneutics," Scriptura 93 (2006), 306.

92 The Earth Bible Team, "Guiding," 38. 
Yet, they play a crucial role in the contemporary re-appropriation of biblical texts, but they must not be confused with the text itself. All constructs must be subjected to a hermeneutics of suspicion in order to allow a free-expression of the text. Obviously, interpretative constructs distort both text and context, bringing certain things into focus, skewing or marginalising others, perhaps ideologically, in prioritising, legitimating and concealing the interests of dominant social groups. ${ }^{93}$

Indeed, while doctrinal constructs enable the interpreter to identify and construct the meaning of the text, they have the potential of leading to a kind of fundamentalism, fixation and rigidity. The text would be merely interpreted in order to confirm what the reader knew would be in the text. As result, no surprises, no challenges, no revelation can be expected from the text other than what the reader constructed in advance.

\section{G CONCLUSION}

Ecological hermeneutics is in its germinating phase. Much still has to be done to nurture this novel approach in biblical studies.

\section{BIBLIOGRAPHY}

Ademiluka, Salomon O. "An Ecological Interpretation of Leviticus 11-15 in an African (Nigerian) Context" Old Testament Essays 22/3 (2009), 525-534.

Anderson, Bernhard W. From Creation to New Creation. Minneapolis: Fortress Press, 1994.

Barr, James. "Man and Nature. The Ecological Controversy and Old Testament." BJRL 55 (1972), 9-32. https://doi.org/10.7227/BJRL.55.1.2.

Bauckham, Richard J. God and the Crisis of Freedom: Biblical and Contemporary Perspectives. Louisville, Kentucky: John Knox, 2002.

Berry, Thomas. The Dream of the Earth. San Francisco: Sierra Club Books, 1988.

Bouma-Prediger, Steven. For the Beauty of the Earth: A Christian Vision for Creation Care. Grand Rapids: Baker Academic, 2001.

Boyer, Paul. When Time Shall Be No More: Prophecy Belief in Modern American Culture Cambridge: Harvard University Press, 1992.

Brady, Veronica. "Preface." Pages 13-17 in Reading From the Perspective of Earth. Ed. Norman C. Habel. Sheffield: Sheffield Academic Press, 2000.

Conradie, Ernest. "The Road towards an Ecological Biblical and Theological Hermeneutics." Scriptura 93 (2006), 305-314.

Conradie, Ernest. "Towards an Ecological Biblical Hermeneutics: A Review Essay on the Earth Bible Project." Scriptura 85 (2004), 123-135. https://doi.org/10.7833/ 85-0-941.

Conradie, Ernest. "What on Earth is an Ecological Hermeneutics? Some Broad Parameters." Pages 295-313 in Ecological Hermeneutics: Biblical, Historical and Theological Perspectives, ed. Horrell, D G, Hunt, C \& Southgate. New York: T\&T Clark, 2010.

93 Horrell, "The Green Bible," 184. 
Cumbey, Constance. The Hidden Dangers of the Rainbow: The New Age Movement and our Coming Age of Barbarism. Lafayette: Huntington House, 1983.

Eaton, Heather. "Ecofeminist Contribution to an Ecojustice Hermeneutics." Pages 5471 in Reading From the Perspective of Earth, ed. Norman C. Habel. Sheffield Academic Press, 2000.

Eckberg, Douglas L and Blocker, Jean. "Christianity, Environmentalism, and the Theoretical Problem of Fundamentalism." JSSR 35 (1996), 343-355.

Esias E. Meyer, "Respect for Animal Life in the Book of Leviticus: How Green were the Priestly Authors?" Old Testament Essays 24/1 (2011), 142-158.

Fowler, Robert B. The Greening of Protestant Thought. London: North Carolina University press, 1995.

Gadamer, Hans-G. Truth and Method. New York: Seabury, 1970.

Gebara, Yvonne. "Cosmic Theology: Ecofeminism and Panentheism," Pages 208-213 in Readings in Ecology and Feminist Theology, eds. Mackinnon, M H \& McIntyre. Kansas City: Sheed \& Ward, 1995.

Groothuis, Douglas R. Confronting the New Age: How to Resist a Growing Religious Movement. Downers Drove: Intervarsity Press, 1988.

Habel, Norman C. "Introducing the Earth Bible." Pages 25-37 in Reading From the Perspective of Earth, ed. Norman C. Habel. Sheffield: Sheffield Academic Press, 2000.

Habel, Norman C. "The Origins and Challenges of an Eco-justice Hermeneutics," Pages 290-306 in Relating to the Text: An Interdisciplinary and Form-Critical Insights on the Bible. eds. TJ Sandoval and C Madolfo. New York: T\&T Clark, 2003.

Habel, Norman C. The Birth, the Curse and the Greening of Earth: An Ecological Reading of Genesis 1-11. Sheffield: Sheffield Phoenix Press, 2011.

Hegel, Friedrich, Lectures on the Philosophy of Religion: Introduction and the Concept of Religion. Vol.1. Berkeley/Los Angeles/London: University of California Press, 1984.

Hierbert, Theodore. The Yahwist's Landscape: Nature and Religion in Early Israel. New York/Oxford: Oxford University Press, 1996.

Horrell, David G. "The Ecological Challenge to Biblical Studies." Theology 112 (2009), 163-171. https://doi.org/10.1177/0040571X0911200302.

Horrell, David G. "The Green Bible: A timely Idea Deeply Flawed." ExpT 121/4 (2010), 180-186. https://doi.org/10.1177/0014524609354743.

Horrell, David G., Hunt, Cheryl, and Southgate, Christopher. "Appeal to the Bible in Ecotheology and Environmental Ethics: A Typology of Hermeneutical Stances." SCE 21/2 (2008), 219-238. https://doi.org/10.1177/0953946808094343.

Horrell, David G. The Bible and the Environment: Towards a Critical Ecological Biblical Theology. London, Oakville: Equinox, 2010.

Johnson, Elisabeth A. "Losing and Finding Creation in the Christian Tradition." Pages 3-22 in Christianity and Ecology: Seeking the Wellbeing of Earth and Humans. Cambridge: Harvard University Press, 2000.

Kestler-D'Amour, Jilian. "US president is rolling back the country's efforts to fight climate change. Here's a look at what he has done so far", One year under Trump: Attack on Climate change fight, 17 January 2018. https://www.aljazeera.com/news/2017/12/explained-donald-trump-attackenvironment-171203184502851.html. 
Lim, Johnson T.K. A Strategy for Reading Biblical Texts. New York: Peter Lang, 2002. Limburg, James. "The Responsibility of Royalty: Genesis 1-11 and the Care of the Earth." WW 11/2 (1991), 124-130.

Loader, James A. "Image and Order: Old Testament Perspectives on Ecological Crisis," in Are we killing God's Earth? Ecology and Theology, Edited by Vorster, V S. Pretoria: UNISA Press, 1987.

Marlow, Hillary. Biblical Prophets: Contemporary Environmental Ethics. New York: Oxford University Press 2009. https://doi.org/10.1093/acprof:oso/978019956905 $\underline{2.001 .0001 .}$

Masenya, Madipoane J. "An Ecobosadi Reading of Psalm 127:3-5.” Pages 109-122 in The Earth Story in the Psalms and the Prophets, ed. Norman C. Habel. Sheffield: Sheffield Academic Press, 2001.

Mellor, Mary. Feminism and Ecology. New York: New York University Press, 1997.

Mueller-Vollmer, Kurt M. "Language, Mind, and Artefact: An Outline of Hermeneutics theory since the Enlightenment." Pages 1-53 in The Hermeneutics Reader, ed. Kurt Mueller-Vollmer (Oxford: The Continuum, 1985).

Nicola H. Creegan, "Theological Foundations of the Ecological Crisis." Stimulus 12/4 (2004), 30-34.

Palmer, Richard E. Hermeneutics. Evanston: North-Western University Press, 1969.

Plumwood, Val. Feminism and the Mastery of Nature. New York: Routledge, 1993.

Primavesi, Anne. From Apocalypse to Genesis: Ecology, Feminism and Christianity. Minneapolis: Fortress Press, 1991.

Ruether, Rosemary R. "Eco-Feminism: The Challenge to theology." Pages 97-112 in Christianity and Ecology: Seeking the Wellbeing of Earth and Humans, eds. Hessel, D T \& Ruether, R R. Cambridge: Harvard University Press, 2000.

Santmire, Paul. Nature Reborn: The Ecological and Cosmic Promise of Christian Theology. Minneapolis: Augsburg Fortress Press, 2000.

Schabas, William. Genocide in International Law: The Crime of Crimes. New York: Cambridge University Press, 2009. https://doi.org/10.1017/CBO978051157 5556.

Schmid, Hans H. "Creation, Righteousness, and Salvation: Creation Theology as the Broad Horizon of Biblical Theology." Pages 102-117 in Creation in the Old Testament, ed. Bernhard W. Anderson. Philadelphia: Fortress Press, 1984.

Sider, Ronald J. "Biblical Foundation for Creation Care." Pages 43-49 in The Care of Creation: Focusing Concern and Action, ed. RJ Berry. Leicester: Inter-Varsity Press, 2000.

Steck, Odil H. World and Environment. Nashville: Abingdon, 1980.

Strickland, Spencer. "Beware of Global Warming! (2 Peter 3:6-7)", Saving Earth on human at a time: my people are destroyed for lack of knowledge, 7 August 2008. http://jeremiahdanielmccarver.wordpress.com/2008/08/07/beware-of-globalwarming-2-peter-36-7.

The Earth Bible Team. "Guiding Ecojustice Principles." Pages 38-53 in Reading from the Perspective of Earth, ed. Norman C. Habel. Sheffield: Sheffield Academic, 2000.

Tutu, Desmond. "Foreword." Pages 7-8 in Reading From the Perspective of Earth. Sheffield: Sheffield Academic Press, 2001.

Van Dyk, Peet. "A Cosmological Interpretation of the Old Testament: Ecological Implications. Paper presented at the 6th AASR conference on 'Religion, Ecology 
and the Environment in Africa and the African Diaspora', held from 30 July-2 August 2014, Cape Town.

Van Heerden, Willie. "Dealing with the history-nature dualism in ecological theology." Journal for Semitics 23/2i (2014), 547-568.

Van Heerden, Willie. "Ecological interpretations of the Jonah narrative - have they succeeded in overcoming anthropocentrism?" Journal for Semitics 23/1 (2014), 114-134. https://doi.org/10.25159/1013-8471/2775.

Van Heerden, Willie. "Taking History Seriously in our Understanding of How we Humans Value the World in which we Live. Paper presented at the Conference of the Sustainability Institute on "Christian Faith and the Earth: Respice et Prospice, Stellenbosch 9 August 2012.

Von Rad, Gerhard. "The Theological Problem of the Old Testament Doctrine of creation." Pages 131-143 in the Problem of The Hexateuch and Other Essays. London: SCM Press, 1984.

Warren, Karen P. "The Power and the Promise of Ecological Feminism." Pages 172195 in Reading in Ecology and Feminist Theology, ed. Mackinnon, M H \& McIntyre, M. Kansas City: Sheed \&Ward, 1995.

Watson, Francis. "Strategies of Recovery and Resistance: Hermeneutical Reflection on Genesis 1-3 and its Pauline Reception." JSNT 45 (1992), 79-103. https://doi.org/ 10.1177/0142064X9201404504.

Westermann, Claus. Creation. London: SPCK, 1974.

White, Lynn. "The Historical Roots of Our Ecological Crisis." Science 155 (1967), 1203-1207. https://doi.org/10.1126/science.155.3767.1203.

Wilkinson, Loren. "New Age, New Consciousness, and the New Creation." Pages 6-29 in Tending the Garden. ed. Wesler Granberg-Michaelson. Grand Rapids: Eerdmans, 1987.

Wright, Ernest. God Who Acts: Biblical Theology as Recital. London: SCM, 1952.

Wright, NT. New Heavens, New Earth: The Biblical Picture of Christian Hope. Cambridge: Grove, 1992.

Dr Kivatsi Jonathan Kavusa is a lecturer of Biblical and Ancient Studies at Universite Libre des Pays des Grands Lacs, Goma, Democratic Republic of the Congo. Email: jokakiv@yahoo.fr. ORCID: https://orcid.org/0000-0001-88878843 